\title{
THE POST-NATAL DEVELOPMENT OF THE OVARY AND UTERUS OF THE MERINO LAMB
}

\author{
J. P. KENNEDY, CAROL A. WORTHINGTON AND E. R. COLE* \\ School of Wool and Pastoral Sciences and \\ *Department of Applied Organic Chemistry, \\ The University of $\mathcal{N}$ ew South Wales, \\ Kensington, N.S.W. 2033, Australia
}

(Received 1st February 1973)

\begin{abstract}
Summary. The growth and development, between birth and 33 weeks of age, of the ovaries, uterus and pituitary of Merino lambs were studied at approximately monthly intervals. The ovarian weight at 4 and 8 weeks of age was 6.8 and 10.8 times, respectively, the ovarian weight at birth. At 12 weeks, it had declined significantly and then remained relatively constant to 33 weeks. The uterine weight at 4 weeks was approximately twice the weight at birth, but it did not increase significantly again until 33 weeks. There was a small increase in pituitary weight between 4 and 8 weeks but no significant change thereafter.

The mean numbers of growing and vesicular follicles in the ovaries were $455 \pm 62$ and $935 \pm 208$, respectively, at birth. They increased significantly at 4 weeks, then declined significantly in older lambs. Mean diameters of the largest follicle per ovary and per animal increased steadily from birth to 33 weeks.

Oestradiol-17 $\alpha$ was detected, by thin-layer chromatography, in the urine of all newborn lambs and oestradiol-17 $\beta$ was detected in the urine of one newborn lamb. After birth, oestrogens were not detectable in urine until 33 weeks when oestradiol-17 $\alpha$ was found in two lambs and oestradiol- $17 \beta$ in another.
\end{abstract}

\section{INTRODUCTION}

Large numbers of vesicular follicles have been observed in the ovaries of newborn lambs (Kellas, van Lennep \& Amoroso, 1958; Mansour, 1959; Land, 1970) and Mansour (1959) and Land \& McGovern (1968) have studied follicular development and ovulation in hormone-treated lambs of various ages. Detailed studies of the physiology of puberty and of the induction of ovulation in the prepubertal ewe, however, require more complete data on the changes which occur between birth and puberty, in the gonads and in the reproductive tract.

In this paper, we report on the growth and development of the ovary and uterus of fine-wool Merino lambs from birth to 33 weeks of age and also present estimates of the numbers of growing and vesicular follicles in the ovary at 
different ages. Concurrently, urinary excretion of oestrogens and weights of the pituitary glands were studied.

\section{MATERIALS AND METHODS}

Groups of four fine-wool Merino female lambs, born in September 1965 and run on pasture with their mothers until weaning in December, were slaughtered at $0,4,8,12,16 \cdot 5,20,24$ and 33 weeks after birth. Twenty-four hours before slaughter, lambs were removed from pasture and kept in metabolism cages with access to food and water. During this period, the total amount of urine voided by each lamb was collected and stored at $-4^{\circ} \mathrm{C}$ until analysis for oestrogens. The lambs were weighed immediately before slaughter. Ovaries, reproductive tracts and pituitary glands were removed after slaughter and placed in Bouin's fixative for $48 \mathrm{hr}$, after which they were freed from adhering tissue, blotted dry on filter paper and weighed. Ovaries were embedded in paraffin wax, serially sectioned at $8 \mu \mathrm{m}$ then stained with haematoxylin and eosin and periodic acid-Schiff reagent (PAS). Segments of the uterus from all newborn lambs and from two lambs from the 4-, 8-, 12-, 20- and 33-week groups were embedded, sectioned and stained with PAS-Alcian blue.

Using a 'Projectina' projection microscope, the number of follicles was counted in every fortieth section of each ovary. The nucleolus of the oocyte was used as a marker and the total count of follicles in each ovary was estimated by multiplying the count per section by 40 . Follicles were classed into two groups: (1) those in which the oocyte was surrounded by more than one layer of follicle cells but an antrum was absent (growing follicles) and (2) those in which the oocyte was surrounded by follicle cells between which an antrum had formed (vesicular follicles).

The greatest diameter of the largest vesicular follicle in each ovary was measured on a micrometer screen on the projection microscope. The boundary of the follicle was defined by the membrana propria. In the samples of the uterus, the height of the epithelium lining the lumen was measured in both the caruncular and intercaruncular region. Three measurements were made in each of three positions for each region and the mean height was calculated.

Following thawing of the urine samples, a $70-\mathrm{ml}$ aliquot from each animal was brought to $\mathrm{pH} 4 \cdot 8$ by addition of $0 \cdot 1 \mathrm{~N}-\mathrm{NaOH}$. The aliquots were incubated for $48 \mathrm{hr}$ at $37^{\circ} \mathrm{C}$ with $\beta$-glucuronidase (Sigma Chemical Co.), extracted with ether $(3 \times 50 \mathrm{ml})$ then heated under reflux with $15 \mathrm{vols} \mathrm{HCl} / 100 \mathrm{ml}$. Following further extraction with ether, acidic contaminants were washed out with distilled water. After removal of solvent, the residue was fractionated between $80 \%$ ethanol and light petroleum, and the hydrocarbon layer washed with $80 \%$ ethanol. The combined ethanol fractions were washed with light petroleum.

The extracts were submitted to thin-layer chromatography on activated silica gel with ethyl acetate/cyclohexane/absolute ethanol, 25:65:10, as developing solvent. Oestrone, oestradiol-17 $\alpha$ and $-17 \beta$ and oestriol (all Sigma Chemical Co.) were used as reference standards. Oestrogens were detected by the Kober test (Nocke, 1961), eluted from the silica gel with warm alcohol under a stream of nitrogen, then estimated spectrophotometrically using a Perkin-Elmer 137 spectrophotometer. 


\section{RESULTS}

The average liveweights at slaughter and post-fixation weights of ovaries, uteri and pituitaries are presented in Table 1 . The ovarian weight at 4 and 8 weeks of age was 6.8 and 10.8 times, respectively, the weight at birth. At 12 weeks, it was significantly $(P<0 \cdot 05)$ less than at 4 and 8 weeks and, between 12 and 33 weeks, it was relatively constant at between 3.5 and 5.0 times the weight at birth. The weight of the uterus at 4 weeks was approximately twice

Table 1. Mean liveweights and mean weights of organs of groups of four ewe lambs slaughtered at different ages

\begin{tabular}{|c|c|c|c|c|}
\hline $\begin{array}{c}\text { Age } \\
\text { (weeks) }\end{array}$ & $\begin{array}{l}\text { Liveweight } \\
\quad(\mathrm{kg})\end{array}$ & $\begin{array}{c}\text { Paired } \\
\text { ovarian } \\
\text { weight } \\
(m g)\end{array}$ & $\begin{array}{c}\text { Uterine } \\
\text { weight } \\
\text { (mg) }\end{array}$ & $\begin{array}{c}\text { Pituitary } \\
\text { weight } \\
\text { (mg) }\end{array}$ \\
\hline $\begin{array}{l}0 \text { (birth) } \\
4 \\
8 \\
12 \\
16 \cdot 5 \\
20 \\
24 \\
33\end{array}$ & $\begin{array}{c}2 \cdot 8 \pm 0 \cdot 2^{\mathrm{a}} \\
10 \cdot 5 \pm 0 \cdot 2^{\mathrm{b}} \\
12 \cdot 7 \pm 0 \cdot 9^{\mathrm{bc}} \\
15 \cdot 8 \pm 0 \cdot 5^{\mathrm{cd}} \\
15 \cdot 8 \pm 1 \cdot 7^{\mathrm{cd}} \\
19 \cdot 8 \pm 1 \cdot 9^{\mathrm{d}} \\
17 \cdot 8 \pm 0 \cdot 8^{\mathrm{d}} \\
25 \cdot 6 \pm 1 \cdot 0^{\mathrm{e}}\end{array}$ & $\begin{array}{c}120 \cdot 8 \pm 38 \cdot 4^{\mathrm{b}} \\
826 \cdot 0 \pm 285 \cdot 0^{\mathrm{a}} \\
1304 \cdot 0 \pm 358 \cdot 0^{\mathrm{a}} \\
560 \cdot 0 \pm 238 \cdot 0^{\mathrm{b}} \\
663 \cdot 3 \pm 303 \cdot 0^{\mathrm{b}} \\
638 \cdot 0 \pm 62 \cdot 0^{\mathrm{b}} \\
418 \cdot 0 \pm 94 \cdot 0^{\mathrm{b}} \\
576 \cdot 5 \pm 54 \cdot 4^{\mathrm{b}}\end{array}$ & $\begin{array}{c}993 \cdot 0 \pm 45 \cdot 6^{\mathrm{a}} \\
2032 \cdot 0 \pm 52 \cdot 6^{\mathrm{a}} \\
2626 \cdot 0 \pm 943 \cdot 4^{\mathrm{ab}} \\
2039 \cdot 0 \pm 524 \cdot 4^{\mathrm{a}} \\
2187 \cdot 0 \pm 371 \cdot 4^{\mathrm{a}} \\
2847 \cdot 0 \pm 325 \cdot 5^{\mathrm{ab}} \\
2282 \cdot 0 \pm 469 \cdot 9^{\mathrm{a}} \\
4325 \cdot 3 \pm 1530 \cdot 0^{\mathrm{b}}\end{array}$ & $\begin{array}{l}154 \cdot 0 \pm 14 \cdot 1^{\mathrm{a}} \\
211 \cdot 0 \pm 17 \cdot 6^{\mathrm{a}} \\
206 \cdot 0 \pm 43 \cdot 8^{\mathrm{a}} \\
224 \cdot 0 \pm 93 \cdot 5^{\mathrm{a}} \\
202 \cdot 0 \pm 12 \cdot 3^{\mathrm{a}} \\
209 \cdot 0 \pm 30 \cdot 1^{\mathrm{a}} \\
227 \cdot 2 \pm 30 \cdot 5^{\mathrm{a}}\end{array}$ \\
\hline
\end{tabular}

$\mathrm{a}-\mathrm{e}=$ means \pm S.E. with different superscripts are significantly different $(P<0 \cdot 05)$.

Table 2. Mean number of growing and vesicular follicles per ovary, and mean diameter of the largest vesicular follicle, in ovaries of ewe lambs of different ages

\begin{tabular}{l|c|c|c|cc}
\hline $\begin{array}{c}\text { Age } \\
\text { (weeks) }\end{array}$ & $\begin{array}{c}\text { No. of } \\
\text { ovaries }\end{array}$ & $\begin{array}{c}\text { Growing } \\
\text { follicles } \\
\text { /ovary }\end{array}$ & $\begin{array}{c}\text { Vesicular } \\
\text { follicles } \\
\text { lovary }\end{array}$ & \multicolumn{2}{|c}{$\begin{array}{c}\text { Diameter of largest } \\
\text { follicle (mm) }\end{array}$} \\
\hline 0 (birth) & 8 & $455 \pm 62^{\mathrm{b}}$ & $935 \pm 208^{\mathrm{a}}$ & $1 \cdot 23 \pm 0 \cdot 68^{\mathrm{a}}$ & $1 \cdot 45 \pm 0 \cdot 80^{\mathrm{a}}$ \\
4 & 8 & $683 \pm 98^{\mathrm{a}}$ & $1100 \pm 185^{\mathrm{a}}$ & $2 \cdot 37 \pm 0 \cdot 28^{\mathrm{ab}}$ & $2 \cdot 50 \pm 0 \cdot 32^{\mathrm{a}}$ \\
12 & 6 & $100 \pm 40^{\mathrm{c}}$ & $287 \pm 99^{\mathrm{b}}$ & $2 \cdot 69 \pm 0 \cdot 66^{\mathrm{b}}$ & $3 \cdot 19 \pm 0 \cdot 55^{\mathrm{b}}$ \\
$16 \cdot 5$ & 6 & $53 \pm 19^{\mathrm{c}}$ & $73 \pm 27^{\mathrm{b}}$ & $2 \cdot 82 \pm 1 \cdot 05^{\mathrm{b}}$ & $3 \cdot 50 \pm 0 \cdot 27^{\mathrm{b}}$ \\
20 & 8 & $140 \pm 24^{\mathrm{c}}$ & $80 \pm 12^{\mathrm{b}}$ & $2 \cdot 93 \pm 0 \cdot 97^{\mathrm{b}}$ & $3 \cdot 63 \pm 0 \cdot 70^{\mathrm{b}}$ \\
24 & 8 & $85 \pm 14^{\mathrm{c}}$ & $140 \pm 38^{\mathrm{b}}$ & $2 \cdot 77 \pm 0 \cdot 66^{\mathrm{b}}$ & $2 \cdot 94 \pm 0 \cdot 69^{\mathrm{ab}}$ \\
33 & 8 & $95 \pm 7^{\mathrm{c}}$ & $140 \pm 28^{\mathrm{b}}$ & $3 \cdot 70 \pm 1 \cdot 10^{\mathrm{b}}$ & $4 \cdot 52 \pm 0 \cdot 73^{\mathrm{b}}$ \\
\hline
\end{tabular}

$a, b, c=$ means \pm S.E. with different superscripts are significantly different.

the weight at birth but, after 4 weeks, it did not vary significantly until 33 weeks, when the weight was significantly $(P<0.05)$ greater than at all ages except at 8 and 20 weeks. There was a small increase in pituitary weight between 4 and 8 weeks but little change thereafter. Pituitaries were not collected from the newborn lambs.

Small numbers of follicles were visible macroscopically in the ovaries at birth and from 8 weeks onwards, but large numbers of follicles were present in ovaries at 4 weeks. The mean numbers of growing and vesicular follicles 
at different ages, estimated from counts of microscopic sections, are presented in Table 2. All the ovaries from 8-week-old lambs and from one lamb in both the 12- and 16.5-week-old groups were damaged during processing and were unsuitable for detailed examination.

Mean numbers of both growing and vesicular follicles were large at birth (Table 2; Pl. 1, Fig. 1), larger at 4 weeks (Table 2; Pl. 1, Fig. 2), then smaller at older ages (Table 2; Pl. 1, Figs 3 and 4). The increase in numbers between birth and 4 weeks was significant $(P<0.05)$ as was the decline between 4 weeks and older ages. There was a marked fall in numbers of both types of follicles between 4 and 12 weeks and examination of two of the 8-week ovaries suggested that much of this drop occurred between 8 weeks, when ovarian weight was maximal, and 12 weeks. The presence of many fresh atretic scars in the 12-week ovaries (Pl. 1, Fig. 3) supports this conclusion.

The mean diameter of the largest follicle per ovary and per animal increased progressively (Table 2) except for a small decline between 20 and 24 weeks. Follicle size increased at the greatest rate between birth and 4 weeks. In lambs which were younger than 12 weeks, many of the vesicular follicles were approximately the same size as the largest follicle (Pl. 1, Fig. 2). In older lambs, one or two follicles were usually much larger than the rest (Pl. 1, Fig. 4), thus presenting an appearance similar to that of adult ovaries.

In newborn lambs, some vesicular follicles had a well-developed granulosa layer but in others the granulosa was very thin. The theca layers also may have varied in thickness but the limits of these layers were less clearly defined, especially in early growth. Initiation of antrum formation seemed to occur at an earlier stage of growth in follicles of the newborn than in those of older animals (R. Tassell, unpublished observations). Definite signs of atresia were not seen in growing or vesicular follicles of the newborn but, thereafter, the various stages of atresia defined by Marion, Gier \& Choudary (1968) were observed in many follicles. Early stages of atresia were most common at 4 weeks while, at older ages, contracting atresia was the most usual type with a small number of follicles undergoing collapsing atresia.

The mean height of the uterine epithelium (Table 3), in both the caruncular and intercaruncular areas, was greatest at birth, then declined to its lowest level between 8 and 12 weeks, after which there was an increase. At birth, there were only a few endometrial folds projecting into the lumen and no glands were present. At 4 weeks, however, endometrial folding had increased and there was extensive glandular development in the intercotyledonary area. These trends continued until 33 weeks of age.

Oestradiol-17 $\alpha$ was detected in the urine of all newborn lambs and oestradiol-17 $\beta$

EXPLANATION OF PLATE 1

FIc. 1. Section of ovary from a newborn lamb. A large number of small vesicular follicles is present.

Fic. 2. Ovary from a lamb aged 4 weeks. Many medium-sized vesicular follicles are present and their presence has resulted in enlargement of the ovary.

Fig. 3. Ovary from a lamb aged 12 weeks. Only small numbers of vesicular follicles are present.

Fig. 4. Ovary from a lamb aged 33 weeks. The pattern of development resembles that in the adult with a few growing and vesicular follicles in each size class. 
PLATE I

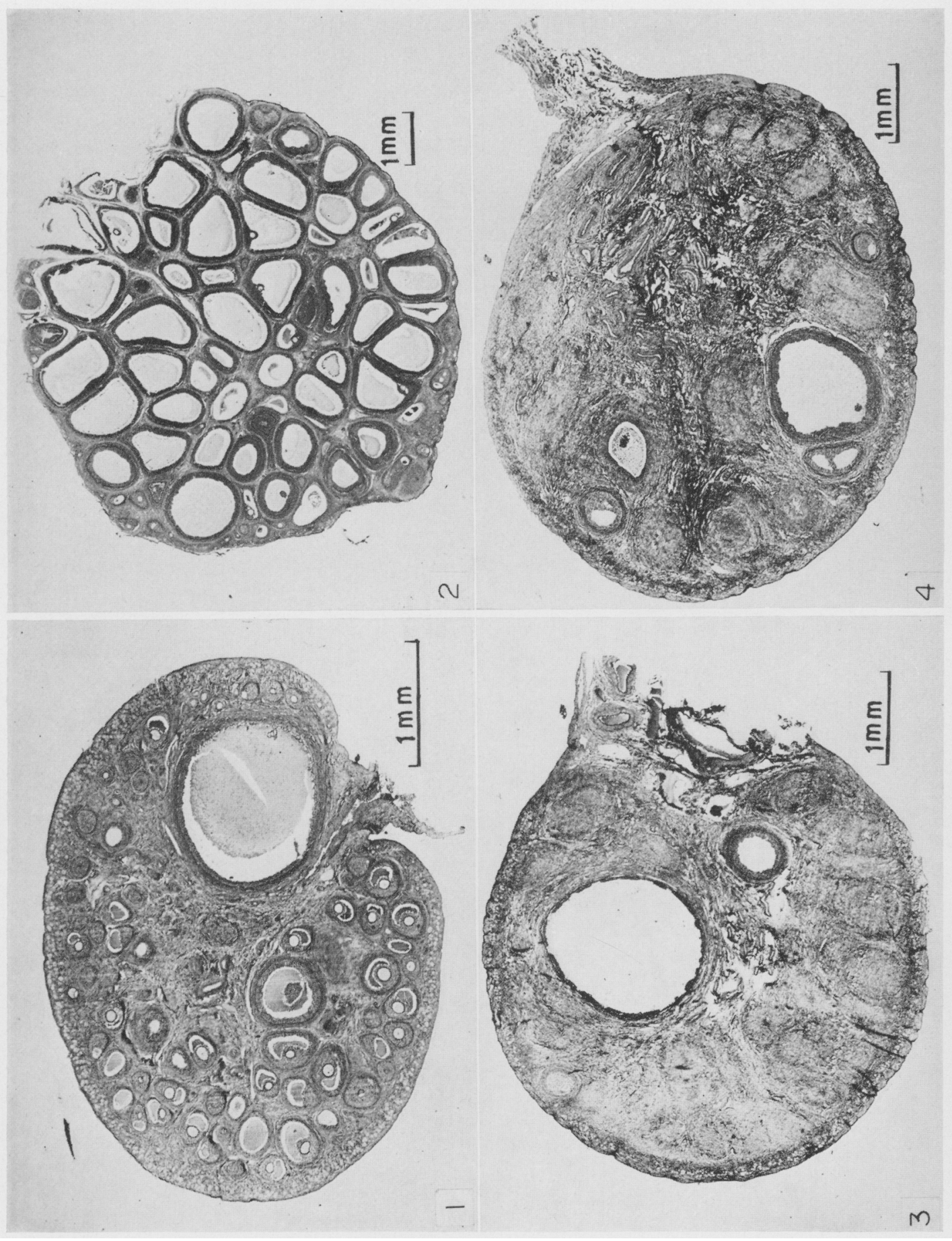

Facing p. 278; 


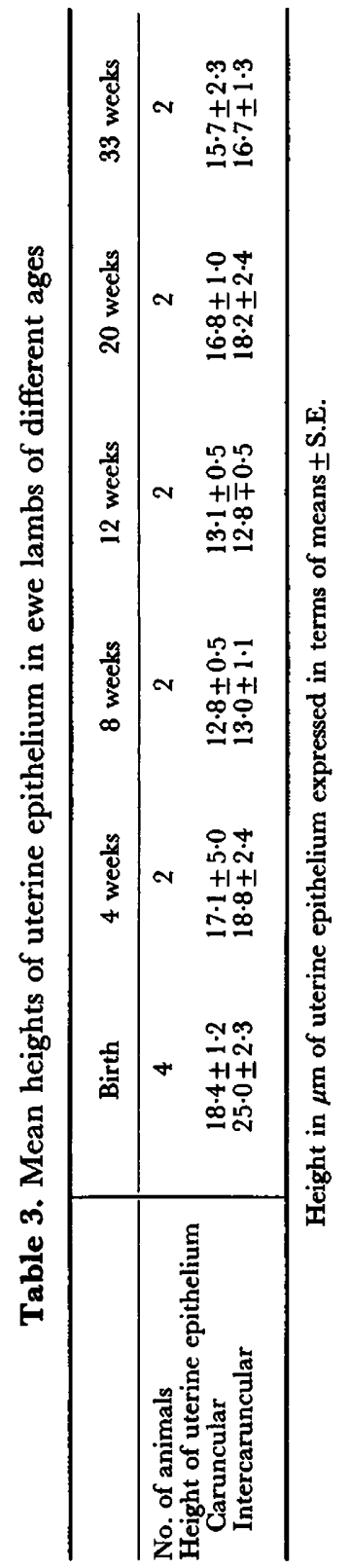


also was detected in the sample from one newborn lamb. Oestradiol-17 $\alpha$ was detected in two, and oestradiol-17 $\beta$ in one of the 33-week-old ewes. Oestrogens could not be detected in the urine of any other animals but, in all samples, the chromatograms contained many interfering substances. In the oestrogen assays, clear separation of the standards was obtained with $R_{\mathrm{F}}$ values calculated as: oestrone, 0.59 ; oestradiol- $17 \alpha, 0.53$; oestradiol- $17 \beta, 0.48$; oestriol, 0.29 . The lower limits of detection were calculated as $0.5 \mu \mathrm{g}$ for oestriol, $0.2 \mu \mathrm{g}$ for oestradiol- $17 \beta$ and $0.07 \mu \mathrm{g}$ for oestradiol- $17 \alpha$ and oestrone.

\section{DISCUSSION}

Notable features of the results presented here are (i) the seven- and elevenfold increase in ovarian weight between birth and 4 and 8 weeks of age, respectively, followed by a decline to a plateau between 12 and 33 weeks, and (ii) the presence of numerous growing and vesicular follicles in the ovary at birth and 4 weeks. Damage during processing prohibited the counting of follicles in 8-week ovaries but it was clear from the microscopic examination that large numbers of growing and vesicular follicles were present. Foster and his co-authors (1972) also observed a sevenfold increase in lamb ovarian weights between Day 148 of pregnancy and Day 18 post partum. In a similar study of Holstein heifers, Desjardins \& Hafs (1969) showed that ovarian weight increased rapidly between birth and 5 months, reached a plateau from 5 to 8 months, then resumed growth from 8 to 12 months. The second period of increase in ovarian weight occurred after oestrous cycles were initiated during the 7 th month of age.

In our study, oestrous cycles were not initiated before the oldest group of lambs was slaughtered. It is likely that first oestrus would not have been observed before the ewes were 13 to 14 months old since Watson \& Gamble (1961) found that Merino lambs, born in the Spring, which did not reach puberty before May were in anoestrus until November or December.

Land (1970) reported follicle counts per ovary of the newborn lamb which ranged from 857 to 1363 growing follicles and 113 to 494 vesicular follicles, in various breeds and crosses. These counts are greater for growing follicles and fewer for vesicular follicles than the counts reported in this paper. Land (1970) used the nucleus as a marker and corrected for nuclear size, while we used the nucleolus as a marker, which may have slightly overestimated the counts since Land (1970) stated that a small proportion of the nuclei in the oocytes of the newborn lamb were found to have more than one nucleolus. Erickson (1966) reported that the number of growing follicles in ovaries of Hereford heifers rose from fifty-three at 1 to 14 days of age to 204 at 60 to 80 days, then remained relatively constant up to 12 months. Counts of vesicular follicles also rose from seven at 1 to 14 days to forty-nine at 60 to 80 days and sixty-three at 180 days following which there was a slight fall in numbers. Erickson (1966) classed as vesicular follicles only those which possessed a 'fully-formed vesicle' while, in this study and that of Land (1970), any follicle in which an antrum had begun to form was classed as vesicular. Despite this difference in methodology, growing and vesicular follicles are much more numerous in the neonatal lamb than in the neonatal calf. 
The pronounced follicular development in the ovary of the newborn is probably the result of gonadotrophic stimulation from the fetal pituitary since Mauléon \& de Reviers (1969) reported that $\mathrm{LH}$ and FSH could be detected in the pituitary of the female sheep fetus from about Day 60 to 80 of pregnancy onwards. Foster et al. (1972) also demonstrated that the pituitary of the fetal and neonatal lamb can synthesize LH which is both biologically and immunologically active, and that LH is found in the fetal and neonatal circulation. Since, however, fetal ovarian growth appears to proceed despite hypophysectomy of the fetus in utero (Liggins \& Kennedy, 1968), we agree with Foster et al. (1972) that regulation of prenatal ovarian development in the lamb remains enigmatic.

Pituitary weight increased slightly between 4 and 8 weeks of age but changed little thereafter. This contrasts with observations that pituitary weight in heifers increased regularly up to 9 months of age (Desjardins \& Hafs, 1968) and, in ram lambs, it increased rapidly from birth to 98 days, then showed no further increase up to 168 days (Skinner, Booth, Rowson \& Karg, 1968). In these rams, the pituitary concentration of FSH increased gradually from birth to 168 days. The concentration of FSH may not be similar in the ewe lamb since there are sex differences in concentration in the fetal lamb (Mauléon \& de Reviers, 1969) and in the prepubertal calf (Desjardins \& Hafs, 1968; Macmillan \& Hafs, 1968). Foster et al. (1972) reported that there was an increase between birth and Day 18 in both serum and pituitary LH in ewe but not in ram lambs, and Land, Thimonier \& Pelletier (1970) reported an increase in plasma LH between 13 and 77 days of age in the ewe.

Vesicular follicles in lambs from 4 weeks onwards appeared to be normal with well developed granulosa and theca layers but, in the newborn, the granulosa was often abnormally thin. These follicles probably appeared atretic at 4 weeks and might be classified as such at birth. It was not until 33 weeks that the largest follicle approached the size of the preovulatory follicle in the mature ewe or of the largest follicle in ewes in anoestrus (Hutchinson \& Robertson, 1966) and in early pregnancy (Tassell, 1971).

The mean height of the intercaruncular uterine epithelium in the newborn was similar to that in the ewe during oestrus and metoestrus and was greater than in the dioestrous ewe (Restall, 1966) and the ovariectomized ewe (Tassell, 1971). Both caruncular and intercaruncular epithelial heights in 4- and 20- to 33-week-old lambs were greater than in ovariectomized ewes (Tassell, 1971) but less than in ewes in the oestrous cycle (Restall, 1966). Heights were similar in 8- and 12-week-old lambs and in ovariectomized ewes. These data suggest that the uterus responded to stimulation by steroids at birth, at 4 weeks and from 20 weeks onwards, but that the greatest response occurred at birth. The detection of oestradiol-17 $\alpha$ and $-17 \beta$ in the plasma of the fetus at term (Findlay \& Cox , 1970) and in urine of the newborn in this study appears to be related to the extensive follicular development and uterine epithelial growth at birth. Urinary oestrogens were not detected in 4- and 8-week-old lambs despite extensive follicular development in the ovaries, though Liefer, Foster \& Dziuk (1972) had concluded that before Day 44 sufficient ovarian steroids were being synthesized and released to affect uterine growth. There is an obvious 
need to apply sensitive methods of assay to determine steroid levels in the blood of prepuberal lambs.

\section{AGKNOWLEDGMENTS}

This work was assisted by a Commonwealth of Australia Postgraduate Scholarship (C.A.W.) and a grant from the Rural Credits Fund of the Reserve Bank of Australia. Dr R. Tassell gave valuable assistance in the preparation of the manuscript.

\section{REFERENCES}

Desjardins, C. \& Hafs, H. D. (1968) Levels of pituitary FSH and LH in heifers from birth through puberty. F. Anim. Sci. 27, 472.

Desjardins, G. \& Hafs, H. D. (1969) Maturation of bovine female genitalia from birth through puberty. F. Anim. Sci. 28, 502.

Erickson, B. H. (1966) Development and senescence of the postnatal bovine ovary. F. Anim. Sci. 25, 800.

Findlay, J. K. \& Cox, R. I. (1970) Oestrogens in the plasma of the sheep foetus. J. Endocr. 46, 281.

Foster, D. L., Roach, J. F., Karsch, F. J., Norton, H. W., Gook, B. \& Nalbandov, A. V. (1972) Regulation of luteinizing hormone in the fetal and neonatal lamb. I. LH concentrations in blood and pituitary. Endocrinology, 90, 102.

Hutchinson, J. S. M. \& Robertson, H. A. (1966) The growth of the follicle and corpus luteum in the ovary of the sheep. Res. vet. Sci. 7, 17.

Kellas, L. M., van Lennep, E. W. \& Amoroso, E. C. (1958) Ovaries of some foetal and prepuberal giraffes (Giraffa camelopardalis Linnaeus). Nature, Lond. 181, 487.

LAND, R. B. (1970) Number of oocytes present at birth in the ovaries of pure and Finnish Landrace cross Blackface and Welsh sheep. 7. Reprod. Fert. 21, 517.

LAND, R. B. \& MaGovern, P. T. (1968) Ovulation and fertilization in the lamb. F. Reprod. Fert. 15, 325.

Land, R. B., Thimonier, J. \& Pelletier, J. (1970) Possibilité d'induction d'une décharge de LH par une injection d'œstrogène chez l'agneau femelle en fonction de l'âge. C.r. hebd. Séanc. Acad. Sci., Paris, 271, 1549.

Liefer, R. W., Foster, D. L. \& Dziuk, P. J. (1972) Levels of LH in the sera and pituitaries of female lambs following ovariectomy and administration of estrogen. Endocrinology, 90, 981.

Liggins, G. G. \& KenNedy, P. C. (1968) Effects of electrocoagulation of the foetal lamb hypophysis on growth and development. J. Endocr. 40, 371.

Macmillan, K. L. \& Hafs, H. D. (1968) Pituitary and hypothalamic endocrine changes associated with reproductive development of Holstein bulls. F. Anim. Sci. 27, 1614.

Mansour, A. M. (1959) The hormonal control of ovulation in the immature lamb. F. agric. Sci., Camb. 52, 87.

Marion, G. B., Gier, H. J. \& Choudary, J. B. (1968) Micromorphology of the bovine ovarian follicular system. 7. Anim. Sci. 27, 451 .

Mauléon, P. \& De Reviers, M.-M. (1969) Variations avec l'âge et le sexe des teneurs en hormones folliculo-stimulante (FSH) et lutéinisante (LH) des ante'hypophyses de foetus de mouton. Annls Biol. anim. Biochim. Biophys. 9, 475.

Nocke, W. (1961) A study of the colorimetric estimation of oestradiol-17 $\alpha$, oestradiol-17 $\beta$, oestrone, oestriol and 16-epioestriol by the Kober reaction. Biochem. 7. 78, 593.

Restall, B. J. (1966) Histological observations on the reproductive tract of the ewe. Aust. F. biol. Sci. $19,673$.

Skinner, J. D., Booth, W. D., Rowson, L. E. A. \& Karg, H. (1968) The post-natal development of the reproductive tract of the Suffolk ram, and changes in the gonadotrophin content of the pituitary. 7. Reprod. Fert. 16, 463.

TASSELL, R. (1971) The histological study of pituitary-gonadal relationships in the sheep. Ph.D. thesis, University of New South Wales, Sydney.

Watson, R. H. \& Gamble, L. C. (1961) Puberty in the Merino ewe with special reference to the influence of season of birth upon its occurrence. Aust. J. agric. Res. 12, 124. 